\title{
THE RADICALIZATION PROGRAM OF PHENOMENOLOGY OF JEAN-LUC MARION
}

\author{
PhD. Piotr KARPIŃSKI, \\ Pontifical Faculty of Theology in Warsaw \\ Higher Seminary in Łowicz, \\ POLAND, \\ Email: piotrkar@o2.pl
}

\begin{abstract}
The article discusses the project of radicalization of phenomenology in Jean-Luc Marion. The very idea of radicalization has been associated with phenomenology since its origin and means a return to the main idea to study the appearance of phenomena, rethink it and draw the maximum consequences from it. Marion argues with Husserl and Heidegger, who, in his opinion, stopped halfway in the phenomenological path: the first reducing all phenomena to objects, the second reducing everything to being. Meanwhile, Marion is about freeing the phenomenon so that it appears on its own and as it is. In this purpose, he adopts the fundamental principle of phenomenology as "so much reduction, so much givenness", which shows that he bases his project on two concepts: reduction and givenness. The next step is to develop the issue of givenness and describe phenomena in its light. Marion's precious discovery is the saturated phenomena, which are characterized by an excess of visibility relative to the concept. Marion's project is completed with an analysis of the gift and the subject. It should be noted that, despite polemics, Marion's phenomenology is an interesting and successful attempt to radicalize phenomenology. Its valuable contribution is reflection on the fundamental principles of phenomenology, which gains value especially in the time of various "applied phenomenologies".
\end{abstract}

Keywords: gift; givenness; Marion; phenomenology; reduction; saturated phenomenon; subject;

\section{INTRODUCTION}

The phenomenological method was formulated in the early work of Edmund Husserl Logische Untersuchungen (Logical investigations) ${ }^{1}$. Although it was clearly polemical with psychologism and cognitive naturalism, its novum lies in the discovery of the difference between what appears and the appearance itself. Phenomenology is not to deal with the subject sphere, but to appearing itself ${ }^{2}$. However, as demonstrated by Jan Patočka, developed by Husserl in later works, from Ideas ${ }^{3}$ to The Crisis ${ }^{4}$, transcendental phenomenology is only one possible implementation of the phenomenological method ${ }^{5}$. It involves a reduction to

\footnotetext{
${ }^{1}$ Edmund Husserl, Logische Untersuchungen, Bd. 1-2, Max Niemeyer Verlag, Halle, 1913.

${ }^{2}$ Philippe Huneman, Estelle Kulich, Introduction à la phénoménologie, Armand Colin, Paris, 1997, p. 18.

3 Edmund Husserl, Ideen ze einer reinen phänomenologie und phänomenologischen Philosophie, Max Niemeyer Verlag, Halle, 1913.

${ }^{4}$ Edmund Husserl, Die Kreisis der europäischen Wissenschaften und die transzendentale Phänomenologie, in: "Philosophia", Bd. 1, Belgrad, 1936.

5 Jan Patočka, Der Subjektivismus der Husserlschen und die Möglichkeit einer “asubjektiven” Phänomenologie, in: "Philosophische Perspektiven", 2 (1970), p. 317-334.
} 
pure immanence, to the subject or transcendental consciousness, which in turn met with criticism of Husserl's students, as well as Martin Heidegger. The next generations of phenomenologists did everything to return to the beginning, to the first phenomenological intuition in Logical investigations.

The idea of radicalization of phenomenology, in the sense of a return to the roots, to the original program, has been present in phenomenology almost from the very beginning. This means that recognition of it as a method goes hand in hand with disappointment as to specific implementations and applications. One of the first programs for the radicalization of phenomenology was formulated by Heidegger in the work Sein und Zeit (Being and Time) ${ }^{6}$ and in his continuing lecture Die Grundprobleme der Phänomenologie (The Basic Problems of Phenomenology) ${ }^{\top}$. According to Heidegger, in order to understand phenomenology one should explain the two words from which this name originates: phenomenon and logos. This first term means "showing-itself-in-itself" ${ }^{\circ} \operatorname{Logos}$, on the other hand, is to bring to light, to make manifest what one is talking about ${ }^{9}$. In phenomenology, therefore, the point is to see what is being shown, as it is to be seen from its own side ${ }^{10}$. Phenomenology has no subject matter but examines the way something is and appears. And the real phenomenon is being. Heidegger's phenomenology is an attempt to reach further than just the objectivity or subjectivity of something - it is an attempt to reach the very sense of being. And since its task is to bring out being as a being, it becomes an ontology.

Phenomenology has undergone intensive development in the Francophone environment, where not only studies of new phenomena have appeared, but also new programs for radicalization of phenomenology have been formulated, which in turn meant further polemics with Husserl and Heidegger. One of the most interesting approaches to phenomenology is the work of Jean-Luc Marion, which we intend to extract and present in this article. The main reason Marion rejects the phenomenology of Husserl and Heidegger is too much conditioning of the phenomenon, i.e. its dependence either on the subject or on being $^{11}$. Whereas, the phenomenon must be released, and one should struggle for it to speak by itself and in the way it wants ${ }^{12}$. The phenomenon should not be kept in the subject-object or noetic-noematic schema, but as an event that transcends human concepts and is completely surprising. What does Marion's radicalization program of phenomenology consists of? First, it is to discuss the phenomenological principles in the search for the most fundamental one. Then research on phenomenological reduction and the discovery of givenness as the final instance of phenomenality. In the third step, Marion performs a specific typology of phenomena, treating them more event-related, which lead him to discover the saturated phenomenon. Finally, as a result of the radicalization of phenomenology, the concept of the subject changes, which is not so much constituting the objective sense as it is the recipient. We will follow these issues, and finally recall some critical voices that have been formulated in relation to Marion's phenomenology.

\footnotetext{
${ }^{6}$ Martin Heidegger, Sein und Zeit, Niemeyer, Tübingen, 1960.

${ }^{7}$ Martin Heidegger, Die Grundprobleme der Phänomenologie, Vittorio Klostermann, Frankfurt, 1975.

${ }^{8}$ Martin Heidegger, Sein und Zeit, p. 47. All translations in this paper by Piotr Karpiński, unless otherwise noted.

${ }^{9}$ Ibidem, p. 52.

${ }^{10}$ Ibidem, p. 54-55.

${ }^{11}$ Jean-Luc Marion, La rigueur des choses. Entretiens avec Dan Arbib, Flammarion, Paris, 2012, p.124.

12 Jean-Luc Marion, Étant donné. Essai d'une phénoménologie de la donation, PUF, Paris, 1997, p. 33.
} 


\section{A MATTER OF PRINCIPLES}

The indication of the primary phenomenological principle is the first step in Marion's phenomenological program. This undertaking should seem a fairly easy, given that Husserl formulated several principles of phenomenology that determine its method and foundation. However, Marion wants to point out one fundamental principle. Husserl has formulated several of them, but they invalidate and abolish each other, and above all lose the idea of primality. Is it possible to indicate one, indisputable phenomenological principle? This question resembles a Cartesian starting point and the search for inconcussum quid. Thus, along with the search for the primary principle, phenomenology in Marion's vision should become not so much an ontology as in Heidegger, but the first philosophy ${ }^{13}$. For this purpose it is necessary to examine the fundamental principles of classical phenomenology, as Michel Henry had already done ${ }^{14}$, and see if any of them could be the first principle.

In Husserl's phenomenology, three fundamental principles can be identified: "so much appearance, so much being" "15 "back to the things themselves" 16 and the principle of all principles according to which "every originary presentive intuition is the legitimizing source of cognition" $"$. The first of these is borrowed from the Marburg school and was formulated by J. F. Herbart far before Husserl. It is an anti-Platonic formula in which doxa, sensual knowledge is equated with being. It can be said that being and appearing have the same ontological dignity. What's more, Husserl admitted the primacy of appearing, because only what appears can reveal the only face of being. There is no being apart from what appears. However, the question immediately arises: what operation allows what appears to achieve the status of being? And besides, is not confusion or at least identification of both appearance and being, the end of phenomenological research? The correlation between being and appearing is unclear. What is grounded in what: appearing in being or being in a phenomenon? Hence, the ambiguity and imprecision of this principle must be stated. It remains largely metaphysical, or at least pre-phenomenological, and is unsuitable for the principle of phenomenology as the first philosophy ${ }^{18}$.

The second principle, "back to the things themselves", in its German formulation (Auf die Sachen selbst zurückgehen) emphasizes both the very return to the things and its necessity and even urgency. But what does "back to the things" mean? Certainly, this cannot mean a return to dealing with beings, objects, things that are already there, because it would again mean the primacy of ontology over phenomenology. According to Marion, one should return to things in the sense of matter, a spoken thing (Fr. chose en question; Ger. Sache), and not in the sense of the object (Fr. objet; Ger. Ding) ${ }^{19}$. The phenomenon consists in the appearance of things beginning with itself and as itself, which in turn privileges not so much

\footnotetext{
${ }^{13}$ Jean-Luc Marion, De surcroît. Études sur les phénomènes saturés, PUF, Paris, 2001, p. 16.

${ }^{14}$ Michel Henry, Quatre principes de la phénoménologie, in: Phénoménologie de la vie. Tome I. De la phénoménologie, PUF, Paris, 2003, p. 77-104. Michel Henry, Incarnation. Une philosophie de la chaire, Seuil, Paris, 2000, p. 41-47.

15 Jean-Luc Marion, Étant donné, p. 18. In the footnote Marion explains that the formula was originally formulated by J. F. Herbart, and then appeared in $\S 46$ of Husserl's Cartesian Meditations and in $\S 7$ of Heidegger's Being and Time.

${ }^{16}$ Jean-Luc Marion, Étant donné, p. 19. In the footnote Marion explains that the formula appeared twice in Husserl: in $§ 19$ of Ideas and in work Philosophy as a strict science.

${ }^{17}$ Jean-Luc Marion, Étant donné, p. 20. This formula is found in $\$ 24$ of Husserl's Ideas and in P. Ricoeur, Idées directrices pour une phénoménologie, Gallimard, Paris, 1950, p. 78.

${ }^{18}$ Jean-Luc Marion, Etant donné, p. 19.

${ }^{19}$ Ibidem, p. 19.
} 
perception of something, but allowing to be seen by somebody. Marion postulates, in phenomenology, to move from demonstrating (démontrer) to manifesting (manifester) ${ }^{20}$. While demonstrating means constituting something, manifesting means allowing something to appear starting from itself, without any production or conditioning. Thus, phenomenology in Marion's vision should not be a priori knowledge. It is hard to find these postulates in Husserl, whose principle means that things are already given, which again sets the priority of being over appearance and determines its metaphysical character ${ }^{21}$.

The third principle, formulated in $\S 24$ of the Husserl's Ideas states that every originary presentive intuition is the legitimizing source of cognition, that everything originally offered to us in intuition is to be accepted simply as what it is presented as being, but also only within the limits in which it is presented there. It opposes Leibniz's principle of sufficient reason, which required the phenomenon to be well established. In his opinion, mere appearance does not sufficiently satisfy the phenomenon, hence the reference to reason. Leibniz's position is continued by Kant, according to which intuitions without concepts are blind - the visibility of something is not enough to justify the phenomenon. Husserl opposes this requirement of an external foundation for the phenomenon. Its mere visibility, appearance, is a sufficient source of the validity of cognition. At the same time, Husserl expanded Kant's concept of intuition - it is not limited only to the sensual sphere, but also includes categories. Intuition or visibility gives us the whole phenomenon. However, the principle of all principles has its limitations: by intuition, everything is present in consciousness and captured as an object. Thus, intuition does not ask about the way of giving the phenomenon, but is subordinated to objectivity and its intentional consciousness. The principle of all principles cannot be the first principle of phenomenology, but it even suppresses any phenomenality that would not be the object of intentional consciousness.

Marion's first stage of phenomenological research ends with the statement that none of Husserl's principles can be the fundamental one of phenomenology. Or maybe there is no such principle and phenomenology is doomed to be implicit and fuzzy knowledge? Marion, however, follows the sentence that Husserl formulated in the article Philosophy as a strict science: "phenomena should be taken as they are"22. It is here that he finds the fundamental characteristics of the phenomenon: something is given in it. This self-givenness of phenomenon is the most important phenomenological principle. However, it should be referred to reduction, since Husserl writes: "phenomenological reduction in no way means limiting research to the sphere of effective immanence, to the sphere of what is effectively included in the absolute sthis « of cogitatio, but limitation to the sphere of pure data, limitation to the sphere of pure evidence, provided this word is taken in a certain precise sense, which already excludes mediate evidence, and above all excludes all evidence in the loose sense" ${ }^{23}$. Research on evidence, givenness and pure phenomenon led Marion to formulate a new principle of phenomenology: "so much reduction, so much givenness" ${ }^{24}$. It is reduction that allows the phenomenon to be transformed so as to give it the status of pure

\footnotetext{
${ }^{20}$ Ibidem, p. 16.

${ }^{21}$ Pascale Tabet, Amour et donation chez Jean-Luc Marion. Une phénoménologie de l'excès, L'Harmattan, Paris, 2017, p. 40.

22 Jean-Luc Marion, Étant donné, p. 23.

${ }^{23}$ Edmund Husserl, L'idée de la phénoménologie. Cinq leçons, trad. A. Lowît, PUF, Paris, 2004, p. 86.

${ }^{24}$ Jean-Luc Marion, De surcroît, p. 21.
} 
data (pure donné) and only the reduction allows it to reach an absolute givenness ${ }^{25}$, and the latter is the ideal limit of phenomenology. Marion takes up Husserl's idea of the giving nature of intuition, but places it in a broader context, where the givenness is grounded in reduction. The more one reduces, the more things are given to him. The Marion's principle thus exceeds the three principles of Husserl, since the reduction leads to givenness. In this way, Marion discovered the principle of phenomenology as the first philosophy. Phenomenology becomes a phenomenology of givenness, thanks to which the field of phenomenality is expanded, because one can study not only objects, not only what appears, but also phenomena somehow given, although not appearing. However, before considering the givenness itself, we should look at the issue of reduction, which as a fundamental operation must also find a new formulation.

\section{THREE TURNS OF REDUCTION}

Although Marion described reduction as the "inaugural operation",26 of phenomenology, it must also undergo a process of radicalization and deepening. The point is not to reduce, like in Husserl, to eidos, to pure consciousness or to the primordial sphere, but to givenness. The latter, however, may appear only as the reduction is radicalized. How does reduction become radicalized? Reaching the point that is the most root and unconditioned. With it, the givenness expands its field. Hence Marion's principle: "as much reduction, as much givenness" 27 .

Marion in his work Réduction et donation analyzes three turning points in the development of reduction. The first stage was Husserl's transcendental reduction, which reduced phenomena to the I intentional by giving to it constituted objects. Such a reduction thus excluded from phenomenological cognition everything that could not be included as an object, and even more excluded givenness. According to Marion, Husserl's approach is imprecise, at least at the point where he identifies being and beings, forgetting about the ontological difference between them, or reducing all beings to the objects. According to Marion, Husserl is so dazzled by the abundance of given objects that he does not ask for the donation itself, i.e. the givenness and it is the "thing itself" to which one should return ${ }^{28}$. For Husserl, everything is given visible, everything is present. Therefore, transcendental reduction comes to the subject as the I transcendental, beginning from which all phenomenal field opens. Phenomenology becomes transcendental egology" ${ }^{29}$. It rises to "things themselves", but only to a certain extent, reaching its limit in the consciousness. According to Marion, the Husserlian reduction is an abuse of the phenomenological method, because one cannot privilege something that cannot be shown and does not show itself, and which is constituted by the subject - precisely objectivity ${ }^{30}$. Husserl's identification of objectivity and givenness leads to similar confusions. The object is not reduced to givenness, because

\footnotetext{
${ }^{25}$ Fr. donation can be rendered in English as "donation" as well as "givenness", but we use "givenness", a use upon which Marion has insisted. "Donation" keeps open a play between donation as an act ("Mr Smith made a donation to our Community") and donation as a fact ("There was a donation left at the front door"). In other words, "donation" retains the possibility of a giver, and the distinction between act and fact is one Marion himself makes in Étant donné.

${ }^{26}$ Jean-Luc Marion, Étant donné, p. 23.

27 For the first time Marion introduced this principle in Réduction et donation. Recherches sur Husserl, Heidegger et la phénoménologie, PUF, Paris, 1989, p. 303.

${ }^{28}$ Jean-Luc Marion, Réduction et donation, p. 22.

${ }^{29}$ Ibidem, p. 29.

${ }^{30}$ Ibidem, p. 78.
} 
reduction does not achieve givenness, and only the latter makes it possible. According to Marion, the Husserl reduction is insufficient, because it has not got rid of the basic threat to the phenomenon - its constitution, production by the subject ${ }^{31}$. And while reducing everything to objectivity, it remains deeply metaphysical indeed.

The second stage is Heidegger's existential reduction, which resulted from the accusation of forgetting of being. However, it should be noted right away that, according to Marion, Heidegger made the same mistake as Husserl, but while the latter one reduced everything to objects, Heidegger sees the source not in givenness, but in being. Despite this, Heidegger noticed the givenness, expressing it impersonally as es gibt, which Marion translates not as il y a, but as cela donne $e^{32}$. The phenomenon is given to us, and this giving has no objective content, no ontic dimension related to beings. The real phenomenon for Heidegger is being access to which is given by Dasein. Being cannot be considered in the order of beings (ontics), but needs a new horizon, because giving is its way of being. Being has to withdraw from beings - the more it withdraws from beings, the more it gives. This is also the logic of givenness, so being must be considered not in the horizon of beings, but in the horizon of giving. Thus, givenness occurs in Heidegger, both in the early work Sein und Zeit and in later thought, where its anonymity and objectlessness will be further emphasized, and the givenness itself will be replaced by the term Ereignis - event or happening ${ }^{33}$.

Marion, however, estimates that Heidegger failed to grasp the ontological difference between being and beings in the perspective of givenness. In his view, while he saw the givenness as something beyond and above being, he ignored it as something below Ereignis. So, similarly to Husserl, he refuses to recognize the givenness as a phenomenological source operation. According to Marion, Heidegger showed some properties of the givenness, but immediately subordinated it to Ereignis, which rejects it as a phenomenological principle. Both objectivity and being do not recognize givenness as such. Husserl's object and Heidegger's being are rather two modalities of the phenomenon manifestation, two possible horizons of what is given. Marion rejects this previous reductions, because both the object and being, first give themselves as data, and thus within the limits of givenness. The phenomenon may take the way of an object or being, but it could not appear if it had not been given, and thus stands on the foundation of givenness as something original and source. Hence yet above mentioned Marion's principle: "as much reduction, as much givenness". As Marion writes: "the reduction to objectivity, that of Husserl (first reduction), and the reduction to being, that of Heidegger (second reduction), can and must give way to a third position, namely the reduction to givenness" $" 34$.

\section{GIVENNESS OR GIFT WITHOUT BEING}

In Marion's project, givenness is the most radical concept of phenomenology, it is the foundation of both what appears and what does not appear, but somehow is given. The concept of givenness includes all data that concern the subject. What's more, the givenness also includes negative data that does not appear directly in intuition ${ }^{35}$. Nothingness, darkness, emptiness appear to the subject as negations of being, appearing or affecting - Marion will

\footnotetext{
${ }^{31}$ Ibidem, p. 78.

${ }^{32}$ Jean-Luc Marion, Étant donné, p. 56. Jean-Luc Marion, Figures de phénoménologie. Husserl, Heidegger, Levinas, Henry, Derrida, Vrin, Paris, 2012, p. 38.

${ }^{33}$ Jean-Luc Marion, Étant donné, p. 59.

${ }^{34}$ Jean-Luc Marion, La rigueur des choses, p. 131.

${ }^{35}$ Jean-Luc Marion, Étant donné, p. 47.
} 
say that they are given in a way of disappointment ${ }^{36}$. Givenness, therefore, has no limits, it is earlier than being or nothingness. Even any negativity implies givenness. Nonsense and contradiction are also given. Givenness cannot be denied, because then we fall into the vicious circle error, as negation is also given. On the basis of givenness, hermeneutics becomes possible, the task of which is to translate phenomena considered as objects into phenomena given more originally. And the combination of two terms - reduction and givenness - makes it possible to extend phenomenology to non-appearing phenomena, to include phenomenality given, although not visible.

But this still seems insufficient. It is not enough to put together reduction and givenness somewhat externally. The reduction must be carried out in the givenness itself. In other words, the givenness must be freed from any objective and subjective elements, according to Marion's postulate, for the phenomenon to give itself, starting from itself, in its own way, as it is. If something is given, it means that it was given to me. There is a donor behind every phenomenon. If someone can give me something, it is logical that he can be the source of the givenness itself. This problem touches on the transcendence issue. Perhaps Marion introduces the transcendent factor to phenomenology, as a result of which givenness would not be the ultimate concept of phenomenology? Marion demonstrates that the givenness in phenomenology is not only without a donor, but also without the recipient and without the gift itself. In the givenness itself a triple epoche should be carried out: of the donor, of the recipient and of the gift, which distinguishes givenness from the economic exchange ${ }^{37}$.

First, Marion parenthesizes the instance of the recipient. This reduction takes place in three figures: the recipient of the gift is anonymous (such as in a charity event), is an enemy (giving to the enemy is certainly free, because unreciprocated), the endowed is an ingrate $^{38}$. The second step is to parenthesize the donor - here the self-reducing donor is shown in three consecutive figures: the athlete, the lover and the artist (each of them provides a jouissance to recipient, but ignores it because he never knows his taste) ${ }^{39}$. And finally, the third reduction of the gift as such, i.e. showing the situation of non-objectivity of the gift. The first figure in parenthesis of the gift itself is the gift of power. The second figure is giving yourself to the other in your own body. The more the body is treated as an object of economic exchange, the less it is a gift. Finally, the third figure is giving the word - the most unreal of the gift figures ${ }^{40}$. After these three reductions, a pure givenness is revealed that takes place in the non-objective field. Pure givenness cannot be further reduced, because everything else has already been put in brackets.

So givenness has revealed itself in Marion's project as the most source instance of phenomenology. In its horizon, the phenomenon is not dependent on the subject or being, it speaks from itself, starting from itself. Such reduction leads us not to what is given, but to pure giving. The phenomenology of givenness exceeds metaphysics, especially its two principles: the principle of identity and the principle of sufficient reason.

\footnotetext{
${ }^{36}$ Ibidem, p. 91.

${ }^{37}$ Ibidem, p. 140.

${ }^{38}$ Ibidem, p. 143-157.

${ }^{39}$ Ibidem, p. 157-170.

${ }^{40}$ Ibidem, p. 170-187.
} 


\section{TYPOLOGY OF PHENOMENA}

Marion established equivalence between givenness and phenomenality. The question then arises, how does phenomenality manifest and function in terms of givenness? What phenomenality does givenness open and enable? The development of phenomenality and the discovery of new types of phenomena is the next stage of Marion's phenomenological program.

If the phenomenon appears, and to appear it must be given, then the basic factor of givennes cannot be intentionality and object constitution, but intuition, or visibility. Each phenomenon consists of two elements: visibility and intention. Visibility is giving of something, appearing, intuition of a given object to which intention, meaning, fulfillment, concept or notion correspond. This distinction corresponds to Husserl's noesis-noema pair. Both dimensions of the phenomenon must meet with each other: visibility fills the content of a given concept, the concept finds itself in a given visibility. In this way, both instances not only condition, but also reinforce and verify each other.

When intuition fills the intention (concept) completely, we talk about obviousness, evidence, absolute verification. However, complete fulfillment of the concept by visibility is rare. Much more often we are dealing with partial fulfillment of intentions by intuition. Husserl did not, however, raise the third option: when visibility exceeds the concept, and this one gives Marion to think ${ }^{41}$.

Marion distinguishes three types of phenomena depending on the relationship between intuition (visibility) and intention (meaning). First, phenomena that are poor in intuition, like the phenomena of mathematical objects. Their feature is a significant overgrowth of intention (concept) over sensual visibility, which in this case is minimal or completely absent ${ }^{42}$. Secondly, the common-law phenomena, the meaning of which is found as an adequacy of intuition (visibility) and intention (concept). It is here that the constitution of objects is possible. Common-law phenomena can be found, for example, in technical or produced items ${ }^{43}$. Thirdly, the saturated phenomena, where the excess of intuition exceeds objective comprehension ${ }^{44}$. This third kind of phenomena Marion deduces as a conclusion that the givenness is prior to intention, meaning and any other category. Saturated phenomena are constituted in a reverse way - the visible givenness goes beyond any horizon of intentionality or concept. Marion, therefore, advocates the necessity of a phenomenon in which visibility gives incomparably more than what intention could ever have predicted.

The concept of the saturated phenomenon wants to introduce into the horizon of consciousness the phenomena of non-appearing (inapparent) ipseities (soi). It is the result of exceeding the principle of all principles by which Marion wants to extend the limits of phenomenology to all areas of human life. How can we explain the cognition of such phenomena as religion, which transcend the sphere of visibility? Religion is a phenomenon that philosophy excludes. Determine under what conditions this phenomenon is definable or not - this is the challenge that Marion takes on in the issue of saturated phenomena.

The saturated phenomena in Marion's approach are not objects but have the structure of an event. Their features are: surprise, astonishment and unpredictability. The saturated phenomenon cannot be presumed or predicted. It is not something that can appear in accordance with the intentional directness of consciousness. It cannot be adequately

\footnotetext{
${ }^{41}$ Jean-Luc Marion, La rigueur des choses, p. 143-144.

${ }^{42}$ Jean-Luc Marion, Étant donné, p. 365.

43 Ibidem, p. 366.

${ }^{44}$ Ibidem, p. 370-373.
} 
described or included in categories of understanding. It also does not undergo scientific measurement or verification. The saturated phenomenon is an absolute givenness of visibility that exceeds all defined and limiting horizons. It gives itself absolutely and freely. The saturated phenomenon is both possible and impossible - so it is something paradoxical ${ }^{45}$. It is also equipped with ipseity (soi) - it gives itself autonomously as such and by itself, it constitutes itself. Marion gives the saturated phenomenon a unique status, sees in it an autonomous, self-donating phenomenality par excellence.

Marion distinguishes four types of saturated phenomena: the event, the idol, the corporeality and the icon ${ }^{46}$. This is not about metaphors or figures, but about specifying the features of the saturated phenomenon based on Kantian categories. According to Kant, every visibility should be presented according to quantity, quality, relation and modality. Whereas, Marion points to phenomena that exceed this categorical approach.

Determining a phenomenon by quantity is its predictability - each phenomenon has a quantity that can be predicted based on the sum of its parts. Meanwhile, there are saturated, unpredictable phenomena because they exceed the sum of their parts. What Marion describes as an event emerges without a reason known in advance, without any supposition that would make it known in advance. The event cannot be determined by a specific moment, place or experience of the individual. It is a historical event whose effects will be felt by all people, and whose meaning cannot be grasped by any single interpretation ${ }^{47}$.

The second categorical term: each phenomenon has a quality, the level of which determines its reality. Qualities are perceived and constituted in objective senses. Again, there are unbearable saturated phenomena, because they exceed the level of intensity that limited sensitivity can withstand. Marion points to an idol, i.e. a work of $\operatorname{art}^{48}-$ it imposes on the gaze such a level of visibility that it fills it to such an extent that it can no longer deal with the transformation of visibility into an object and no longer experiences this visibility without synthesis as an objective spectacle, but as a state of the subject experiencing something that he is not able to synthesize. We can bring concepts or categories to a work of art, e.g. a picture, but they will not be able to finally capture the excess of sensual visibility of it.

The third category is to describe the phenomenon according to the relationship: no objective phenomenon could appear if it were not associated with another through the concept, like substance and accidents, cause and effect. Meanwhile, instead of connecting to another phenomenon according to the analogies of experience, there are saturated phenomena that are not related to any relation, because they occur without any other reference, except that which relates them to themselves. What is called par excellence corporeality (la chair $)^{49}$, referring only to itself, experiences itself before it can experience something else.

Finally, the category of modality means that no phenomenon can be synthesized into the form of an object unless it relates to the conditions that must be met: formal for possibility, material for actuality and universal for the necessity of experience. Meanwhile, instead of referring to the regard of the subject, according to the postulates of empirical thinking in general, there are saturated phenomena that are free from the requirements of transcendental viewing, phenomena that are unobservable and cannot be constituted into objects within a finite phenomenological field. What is visible in the full sense of the word in

\footnotetext{
45 Ibidem, p. 370.

${ }^{46}$ Ibidem, p. 373.

${ }^{47}$ Ibidem, p. 374-376.

${ }^{48}$ Ibidem, p. 376-378.

${ }^{49}$ Ibidem, p. 378-380.
} 
the face of the other or in the icon, which, facing me, looks at me, not allowing me to look at it. The icon is what provides nothing to the gaze and which, being inaccessible to the viewer, nevertheless keeps its gaze on it. The icon is the other's look at me ${ }^{50}$.

What makes saturated phenomena inconvenient to learn does not come from difficulties in experiencing them, but from an excess of intuition. Although their phenomenality is characterized by an excess of uniqueness, they are rather banal and common in our experience. However, they dissolve in the dazzle caused by the excess of intuition, and this is not about dazzle as the sensitivity of the eyes to the light excess, but as the inability to designate the concept of intuition, which gives nothing but itself. Hence, the saturated phenomenon is not present in any direct experience. What's more, it even enables counter-experience (contre-expérience) ${ }^{51}$, which we can define as a negative experience, an outflow of intuition that hides the form of what is withdrawing and can only be known by the resistance it puts on my intentional look. Negative experience confirms the presence of the saturated phenomenon, but at the same time makes it inaccessible.

We can see now how Marion reverse our objective attitude to the world, turning Kant's categories of understanding. Saturated phenomena appear by themselves and transcend any human notion. Only the saturated phenomenon appears by itself, starting from itself. Marion defines such an independent and possible phenomenon as revelation, but he explains: "by revelation, we mean here a strictly phenomenological concept: an appearance purely from oneself and starting from oneself" ${ }^{52}$. Revelation combines all four saturation figures and become its fifth type - saturation of the saturation ${ }^{53}$. It is not a paradox, but a paradox of paradoxes, which Marion describes as a paradoxotaton ${ }^{54}$ - the most surprising.

\section{SUBJECT AS L'ADONNÉ}

Description of the free and possible phenomenon, starting from itself, leads us to the last point of the phenomenological program of Marion. The phenomenon as an event, as a given, as saturating visibility is neither an object nor a being, but something given, and even a givenness. This already indicated a great distance of phenomenology towards metaphysics, which is part of the idea of exceeding metaphysics in 20th-century philosophy ${ }^{55}$. However, the subject side remains to be clarified: to whom is the phenomenon given? Let us remember that in Husserl reduction meant reducing the phenomenon to immanence, that is, to constitutive and intentional consciousness, which made the phenomenon dependent on the subject, almost created by it. So what role does the subject play in Marion's phenomenology? What is his idea of subjectivity?

Certainly, the subject in Marion's phenomenology takes a secondary position to the phenomenon and givenness ${ }^{56}$. The phenomenon is prime because it comes first before any subject. Marion strongly emphasizes that the subject is not the producer of the phenomenon.

\footnotetext{
${ }^{50}$ Ibidem, p. $380-383$

${ }^{51}$ Ibidem, p. 353.

52 Jean-Luc Marion, Le phénomène saturé, in: Michel Henry, Paul Ricoeur, Jean-Luc Marion, Jean-Louis Chrétien, Phénoménologie et Théologie, Criterion, Paris, 1992, p. 127.

${ }_{54}^{53}$ Jean-Luc Marion, Étant donné, p. 397.

${ }^{54}$ Ibidem, p. 385.

${ }^{55}$ Jean-Luc Marion, La «fin de la métaphysique » comme possibilité, in: Heidegger, red. M. Caron, Cerf, Paris, 2006, p. 11-38.

${ }^{56}$ Stéphane Vinolo, Dieu n'a que faire de l'être. Introduction à l'œuvre de Jean-Luc Marion, Germina, Paris, 2012, p. 61.
} 
It should not be understood as a source of appearance, but as a its witness ${ }^{57}$. The subject has a secondary position, which also means a grammatical change from the nominative (Lat. nominativus; Fr. nominatif) to the dative (Lat. dativus; Fr. datif). The subject is not a "who" (nominative), but "to whom" (dative) is to give a testimony ${ }^{58}$. The subject follows the phenomenon - it is not its producer or condition, but a witness and recipient. Marion describes this new type of subjectivity as l'adonne ${ }^{59}$. The Cartesian ego is deprived of its transcendental purpose. The subject must admit that he receives the phenomenon, is endowed with it, and it is the fact of giving that makes him who he is. The phenomenon, therefore, by giving itself, simultaneously gives the subject to himself. The subject reaches himself only through the gift and discovers himself as the recipient (l'adonné).

However, several questions arise regarding this concept of the subject. First, does not considering the subject as l'adonné mean the end of the idea of subjectivity and a return to the ordinary empirical ego? Secondly, since the phenomenon is active and the subject as l'adonné only receives, it means that it is completely passive - so do we not return to classical metaphysics with an active thing and a passive mind? Is this concept of the subject not a turn of the Copernican revolution, or the discovery of the active role of the subject in Kant? Marion is aware of these doubts, but points out that his goal is not to simply reverse the hierarchy in such a way that what was active becomes passive and conversely. Marion argues that all oppositions, like subject-object or active-passive, are illusory. The subject as l'adonné should be thought outside of them. As he writes: "l'adonné exceeds both passivity and activity, because, by freeing itself from the transcendental purple, it cancels the distinction between the transcendental I (le je transcendental) and the empirical self (le moi empirique $)^{\prime 60}$. Moreover, Marion undertakes to prove that receiving and being gifted does not necessarily mean radical passivity. This is because receiving also means some work to be done. For something to be given, the subject must be able to receive. This explains why we do not receive everything at once, for example at birth, which is a hidden polemic with nativism, but all our lives we must become able to receive with every event of the day. The recipient recognizing himself as such makes himself capable of receiving and enables the givenness event. The subject only accepting thinking of himself as the recipient allows that what comes to appear as a gift. Thus, receiving a gift as a gift and enabling its visibility as such is not pure passivity, since the recipient must first accept it and recognize it as a gift. Two things should not be confused here: receiving as pure passivity and revealing the gift, recognizing something as a gift from the recipient. By making it possible to see what is given the subject as l'adonné becomes a screen (ecran $)^{61}$.

\section{CONCLUSIONS AND CRITICISM OF MARION'S PHENOMENOLOGY}

We may conclude that the entire phenomenological project of Marion is an attempt to return to the original program formulated by Husserl in Logical investigations and to draw the maximum consequences from it. Marion wants to free the phenomenon from any conditions so that it can appear on its own initiative and present itself as it is. Therefore, the phenomenon cannot be the object, but also it cannot be dependent on the subject. Thanks to such outlined program, Marion not only overpasses metaphysics, but also extends the

\footnotetext{
${ }^{57}$ Jean-Luc Marion, Étant donné, p. 405.

58 Ibidem, p. 373.

${ }^{59}$ Ibidem, p. 427.

${ }^{60}$ Jean-Luc Marion, De surcroît, p. 57.

${ }^{61}$ Ibidem, p. 59.
} 
possibilities of phenomenology, which can study non-appearing phenomena that have no object structure but events.

The phenomenological principles formulated by Husserl proved to be insufficient, metaphysical and pre-phenomenological. The ideal term to phenomenology is not transcendental awareness, but givenness - everything that appears is given first. What's more, there are phenomena somehow given to us, but which do not appear. Hence the fundamental phenomenological principle, according to Marion, should be: "so much reduction, so much givenness". The reduction reveals various degrees of what is given to us. The reduction of Husserl (to the object) and Heidegger (to being) stopped halfway. To really reduce something is to come to the fact that the phenomenon is given, and then to parenthesize three instances: the giver, the recipient and the gift itself. The effect of such reduction is givenness as a essential concept of phenomenology.

What is given has various degrees of phenomenality. Marion distinguishes three types of phenomena: poor in intuition, common-law and saturated phenomena. While in the first type of phenomena there is a surplus of the concept over visibility (as in mathematical quantities), and in the second type their balance (Husserl recognized only this case), in the saturated phenomenon there is an excess of visibility over the concept. Such a phenomenon becomes an event and comes as a surprise. The saturated phenomenon more reveals to the subject than it is constituted by him. The subject in this approach does not play a primary and source role, does not condition the phenomenon, but receives it, and along with the phenomenon receives himself as the recipient - l'adonné. The subjectivity in Marion is definitely weakened, but it does not mean pure passivity. We would say that the subject's activity is moral and performative - recognizing the phenomenon in the gift enables its visibility as such.

Marion's phenomenology has become the subject of numerous polemics and critics, which, however, only emphasizes its importance in philosophical area. Three main critical voices were formulated by D. Janicaud, J. Benoist and J. Derrida.

Dominique Janicaud made an accusation of "theological turn" against many contemporary French phenomenologists, including Marion ${ }^{62}$. In his opinion, by opening up to non-appearing phenomena, which in itself is a contradiction, they introduced transcendence to phenomenology, and thus did not practice phenomenology but crypto-theology. Janicaud's objection can be described as "theologization of phenomenology". It does not seem right, however, for several reasons. First, starting with Husserl, there are no taboos that phenomenology should not deal with. Secondly, phenomenology, especially in its French formulation, has gone through numerous turns (e.g., aesthetic, anthropological, cognitive turn), and has continually sought to broaden its horizons, the phenomenal field, which is in line with its assumptions. Thirdly, phenomenology is not a field defined by the object, but by the method - phenomenological research is not determined by the "what" of the phenomenon, but by the way it is examined and revealed. Finally, fourthly, we should speak not so much of "theologization of phenomenology" in Marion as of the "phenomenologization of theology". In this approach, the phenomenological method is maintained and begins to bear unexpected fruit in new areas, such as the religious phenomenon, God or revelation.

${ }^{62}$ Dominique Janicaud, Le tournant théologique de la phénoménologie française, Éditions de l'éclat, Combas, 1991. 
Jocelyn Benoist in the work L'idée de la phénoménologie criticized Marion's reduction to givenness ${ }^{63}$. Its effect is a call, an appeal, but it is not known where it comes from, because it consumes the person of its interlocutor. The appeal steaming from the phenomenon in advance reduces itself to its pure form and does not allow to think a word, hence in Benoist's view remains empty, without content. This apriority and transcendence of the appeal shows the relationship between Marion's phenomenology and Christian revelation. So, Benoist sees in Marion's phenomenology a turn, if not towards theology, then at least towards "phenomenology of appeal", which throws it out of the proper field of phenomenology, and becomes more hermeneutics. However, Benoist's objection must be answered that phenomenology should not refuse to speak of God. Phenomenological thinking of God does not necessarily mean crypto-theology. God, as a possible phenomenon, intrigues human, so one should look for his sense. For Marion, such phenomenology becomes a "hermeneutics of love", which is nothing more than a special phenomenology of givenness and love. Speaking of God, Marion never leaves phenomenology.

Polemics with Jacques Derrida is another type. It is not about unilateral accusations, like the above-mentioned voices of Janicaud and Benoist, which rather flowed from inattentive reading Marion, but a mutual polemic about the gift. Marion reads critically the book Donner le temps of Derrida ${ }^{64}$ and discusses it in his book Étant donné, which in turn met with criticism of Derrida. According to Derrida, absolutely pure giving is impossible. If the act of giving is to be pure, then we cannot deal with a returning gift of the giver, because in that case the gift will cease to be a gift and will become the object of economic exchange. Derrida's gift is totally subordinated to economics that will cancel it. There is no logic of the gift that underlies Marion's phenomenology. According to Derrida, Marion is wrong, because any appearance of phenomena does not occur in the horizon of givenness, but is always conditioned by the economy and the process of exchange. Marion, however, is trying to refute these deconstructivist allegations about his phenomenology of givenness and claims that the gift analysis of Derrida cannot be applied to phenomenological givenness. Derrida's mistake is to confuse the phenomenological order and the sociological one. Phenomenological giving is by no means economical, because the gift is given in the framework of the paradoxical logic: "what is given, resulting from the givenness process, appears, but leaves concealed the givenness itself, which becomes enigmatic"65. Giving is detached from the economy of exchange, because giving of oneself is anonymous and its source cannot be determined. The lack of a recognizable giver interrupts the economic exchange cycle. When it comes to appearing, each of the elements of giving - giver, gifted and gift - is put in brackets, i.e. reduced.

Despite the critical voices, Marion's phenomenological project should be considered one of the most interesting and promising. It is a unique attempt to rethink phenomenology in two dimensions: in the dimension of its fundamental principles on the one hand, and in the dimension of new its applications on the other. This is all the more valuable because today hardly anyone deals with the principles of phenomenology, but all sorts of "engaged phenomenologies" and "applied phenomenologies" flourish, such as the phenomenology of psychiatry, artificial intelligence, sex or feminism. Meanwhile, without a thorough reflection on the foundations of phenomenology, we do not know what status these "engaged" statements have and whether they bring us closer to the truth.

${ }^{63}$ Jocelyn Benoist, L'idée de la phénoménologie, Beauchesne, Paris, 2001.

${ }^{64}$ Jacques Derrida, Donner le temps. 1. La fausse monnaie, Galilée, Paris, 1991.

${ }^{65}$ Jean-Luc Marion, Étant donné, p. 115. 


\section{BIBLIOGRAPHY:}

[1] BENOIST Jocelyn, L'idée de la phénoménologie, Beauchesne, Paris, 2001.

[2] DERRIDA Jacques, Donner le temps. 1. La fausse monnaie, Galilée, Paris, 1991.

[3] HEIDEGGER Martin, Die Grundprobleme der Phänomenologie, Vittorio Klostermann, Frankfurt, 1975.

[4] HEIDEGGER Martin, Sein und Zeit, Niemeyer, Tübingen, 1960.

[5] HENRY Michel, Incarnation. Une philosophie de la chaire, Seuil, Paris, 2000.

[6] HENRY Michel, Quatre principes de la phénoménologie, in: Phénoménologie de la vie. Tome I. De la phénoménologie, PUF, Paris, 2003, p. 77-104.

[7] HUNEMAN Philippe, KULICH Estelle, Introduction à la phénoménologie, Armand Colin, Paris, 1997.

[8] HUSSERL Edmund, Die Kreisis der europäischen Wissenschaften und die transzendentale Phänomenologie, in: "Philosophia", Bd. 1, Belgrad, 1936.

[9] HUSSERL Edmund, L'idée de la phénoménologie. Cinq leçons, trad. A. Lowît, PUF, Paris, 2004.

[10] HUSSERL Edmund, Ideen ze einer reinen phänomenologie und phänomenologischen Philosophie, Max Niemeyer Verlag, Halle, 1913.

[11] HUSSERL Edmund, Logische Untersuchungen, Bd. 1-2, Max Niemeyer Verlag, Halle, 1913.

[12] JANICAUD Dominique, Le tournant théologique de la phénoménologie française, Éditions de l'éclat, Combas, 1991.

[13] MARION Jean-Luc, De surcroît. Études sur les phénomènes saturés, PUF, Paris, 2001.

[14] MARION Jean-Luc, Étant donné. Essai d’une phénoménologie de la donation, PUF, Paris, 1997.

[15] MARION Jean-Luc, Figures de phénoménologie. Husserl, Heidegger, Levinas, Henry, Derrida, Vrin, Paris, 2012.

[16] MARION Jean-Luc, La "fin de la métaphysique » comme possibilité, in: Heidegger, red. M. Caron, Cerf, Paris, 2006, p. 11-38.

[17] MARION Jean-Luc, La rigueur des choses. Entretiens avec Dan Arbib, Flammarion, Paris, 2012.

[18] MARION Jean-Luc, Le phénomène saturé, in: Michel Henry, Paul Ricoeur, Jean-Luc Marion, JeanLouis Chrétien, Phénoménologie et Théologie, Criterion, Paris, 1992, p. 79-128.

[19] MARION Jean-Luc, Réduction et donation. Recherches sur Husserl, Heidegger et la phénoménologie, PUF, Paris, 1989.

[20] PATOCKA Jan, Der Subjektivismus der Husserlschen und die Möglichkeit einer "asubjektiven" Phänomenologie, in: "Philosophische Perspektiven", 2 (1970), p. 317-334.

[21] TABET Pascale, Amour et donation chez Jean-Luc Marion. Une phénoménologie de l'excès, L'Harmattan, Paris, 2017.

[22] VINOLO Stéphane, Dieu n'a que faire de l'être. Introduction à l'œeuvre de Jean-Luc Marion, Germina, Paris, 2012. 